\title{
Cavitation of Tumoral Mass after Radiotherapy in a Patient with Pancoast Tumor
}

\author{
Ayşegül Karalezli' ${ }^{1}$, Emine Argüder ${ }^{1}$, Berna Akkuş Ylldırım², Ayşe Nur Soytürk ${ }^{1}$ \\ H. Canan Hasanoğlu ${ }^{1}$
}

${ }^{1}$ Department of Chest Diseases, Ankara Atatürk Training and Research Hospital, Ankara

${ }^{2}$ Department of Radiation Oncology, Ankara Atatürk Training And Research Hospital, Ankara

\begin{abstract}
Radiation-induced lung diseases are common after radiotherapy of the chest wall or intrathoracic organs. The damage of radiations is ground-glass opacity, consolidation, fibrosis, traction bronchiectasis, and volume loss. Development of pleural fluid or a new mass is rarely seen. A solid lesion was detected in the computed thoracic tomography of 53 year-old male patient. The lesion was at the apex of the right lung, $66 \times 61 \mathrm{~mm}$ in size and invading the trachea, esophagus and right subclavian artery. Weekly chemotherapy and radiotherapy were applied concurrently, and the tumor was quickly disappeared, leaving its place to an unexpected cavitary lesion. The case has been reported because of its rarity in the literature.
\end{abstract}

Keywords: Cavity, lung cancer, pancoast, radiotherapy

\section{Özet}

Toraks içi organlara ya da toraks duvarına uygulanan radyoterapi sonrasında radyasyona bağlı akciğer hastalıkları sık görülür. Radyasyona bağlı gelişen hasarlar arasında buzlu cam opasitesi, konsolidasyon, fibrozis, traksiyon bronşektazisi ve volüm kaybı yer alır. Nadir olarak plevral sıvı ya da yeniden kitle oluşumu görülebilir. Elli üç yaşındaki erkek olguda, toraksın bilgisayarlı tomografisinde sağ akciğer apeksinde $66 \times 61 \mathrm{~mm}$ boyutlarında, trakea, özefagus ve sağ subklaviyen arteri invaze eden solid lezyon saptanmış ve uygulanan eş zamanlı haftalık kemoterapi ve konformal radyoterapi sonrasinda lezyonun hizlica yok olup yerini tamamen kaviter lezyona bıraktığı izlenmiştir. Literatürde nadir rastlanması nedeniyel bu olgu sunulmuştur.

Anahtar Kelimeler: Akciğer kanseri, kavite, pancoast, radyoterapi
Received Date / Alındığı Tarih: 17.02.2012 Accepted Date / Kabul Tarihi: 07.07.2012 Available Online Date /

Çevrimiçi Yayın Tarihi: 25.11.2014

Address for correspondence / Yazışma Adresi Emine Argüder, Ankara Atatürk Eğitim ve Araştırma Hastanesi, Göğüs Hastalıkları Kliniği, Ankara, Türkiye

E-mail / E-posta: drgullu2000@gmail.com

(C) Copyright 2014 Turkish Respiratory Society (TRS) Eurasian J Pulmonol 2014

DOI: 10.5152/ejp.2014.27928

-Available online at www.eurasianjpulmonol.com

\section{INTRODUCTION}

Radiation-induced lung diseases after radiation therapy to the thoracic wall or lungs are common. Lungs are one of the most sensitive organs against ionizing radiation. Radiologic findings are usually localized to the lung tissue in the radiation field. Radiation-induced damage varies depending on the dose of radiation, type of radiation, type of fractionation, size of port, and concomitant or previous chemotherapy. In the acute phase, ground-glass opacity or consolidation may occur, whereas in the chronic phase, typically fibrosis, traction bronchiectasis, or volume loss can be seen. Rarely, pleural fluid or development of a new mass is also reported (1,2). Herein, we report a case where the tumor tissue disappeared and was replaced by a cavity after conformal radiotherapy with simultaneous chemotherapy.

\section{CASE PRESENTATION}

A 53-year-old male patient with complaints of right shoulder and neck pain, fever, weight loss, and appetite loss for about 2 months was admitted to our hospital. He had a smoking history of 40 packsyear. In the physical examination, the vital signs were normal, but there were rhonchi in the right subscapular area by auscultation. The postero-anterior (PA) chest radiography revealed homogeneous density in the right upper zone (Figure 1). Thorax computed tomography (CT) was performed, and a solid $66 \times 61-\mathrm{mm}$ mass in the right lung apex extending to the trachea, esophagus, and the right subclavian artery was seen (Figure 2). Spicular extensions from mass to the adjacent lung parenchyma and hypodense areas inside the mass compatible with necrosis were also present. In the bronchoscopy, the right upper lobe bronchus was narrowed with no visible endobronchial lesion. Histopatholog- 


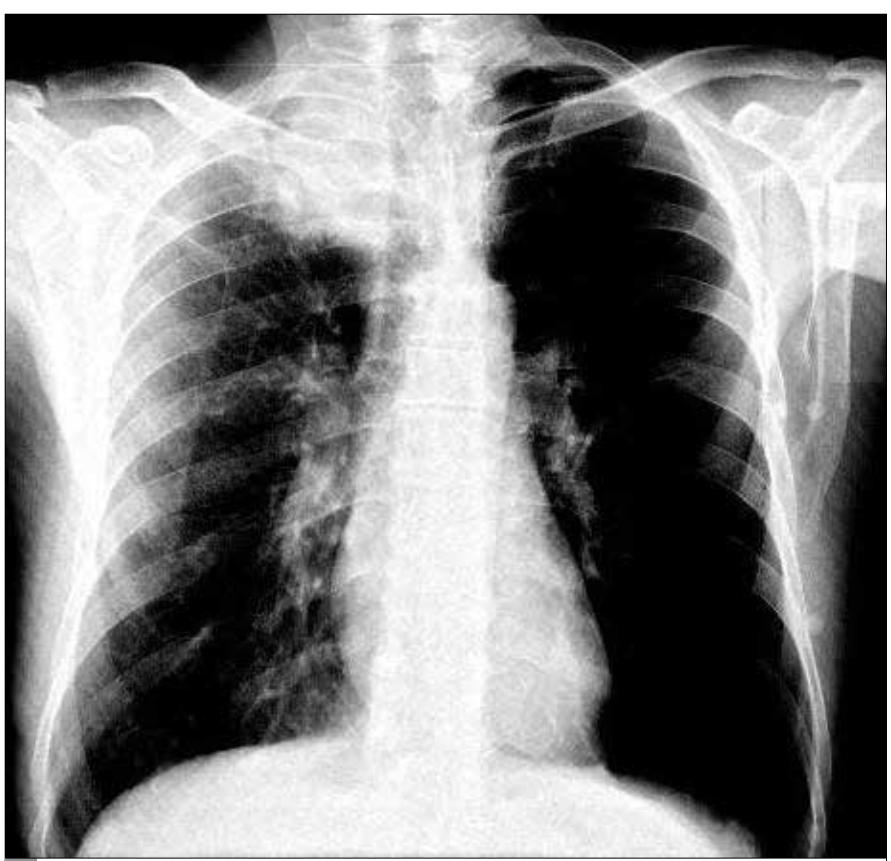

Figure 1. Initial chest X-ray showing homogenous density in the right upper zone.

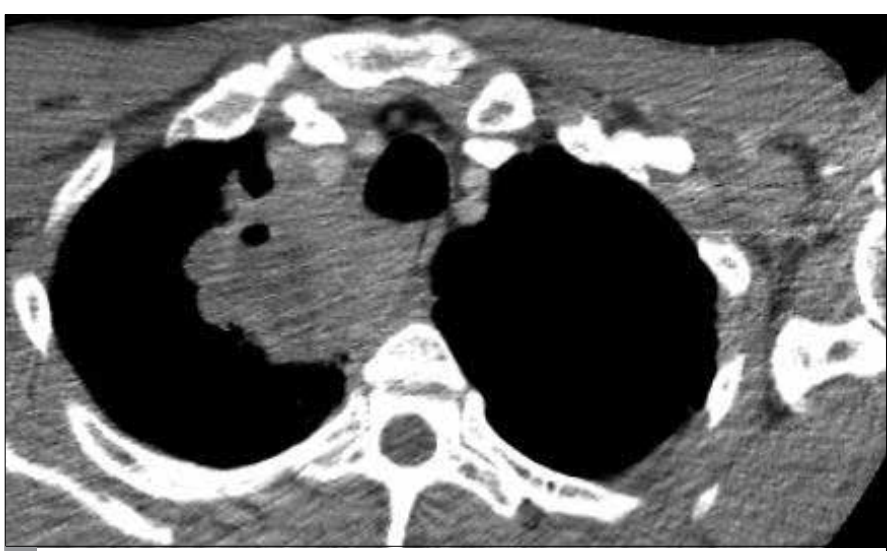

Figure 2. Initial thorax CT showing mass lesion size of $66 \times 61$ $\mathrm{mm}$ in the right upper lobe

ical evaluation of CT-guided transthoracic biopsy showed squamous cell carcinoma. In the magnetic resonance imaging of the brachial plexus, the mass was invading $\mathrm{T} 2, \mathrm{~T} 3$, and the inferior vertebrae and brachial plexus. In the whole-body 18F-FDG PET-CT scan, the mass in the apex of the right lung, right hilar, and mediastinal lymph nodes showed increased FDG uptake. Because the tumor was inoperable, initial treatment with weekly carboplatin and paclitaxel chemotherapy was given simultaneously with daily $200 \mathrm{cGy}$, total of $6000 \mathrm{cGy}$, three-dimensional conformal radiotherapy on the right lung lesion area and lymph nodes for a period of 4 weeks. Then, chemotherapy was continued for 8 more weeks. About 10 days after the last regimen of chemotherapy, he developed fever, cough, and dyspnea. In the physical examination, the temperature was $38.5^{\circ} \mathrm{C}$, oxygen saturation was $95 \%$, and in the lung auscultation, there were decreased breath sounds on the apical region and rhonchi in the right scapula. In the chest x-ray, there was a big cavity in the right upper zone. Thorax CT scan revealed a cavitary lesion with almost the same volume of mass of approximately $56 \times 71 \mathrm{~mm}$ in the same place (Figure 3 ). There

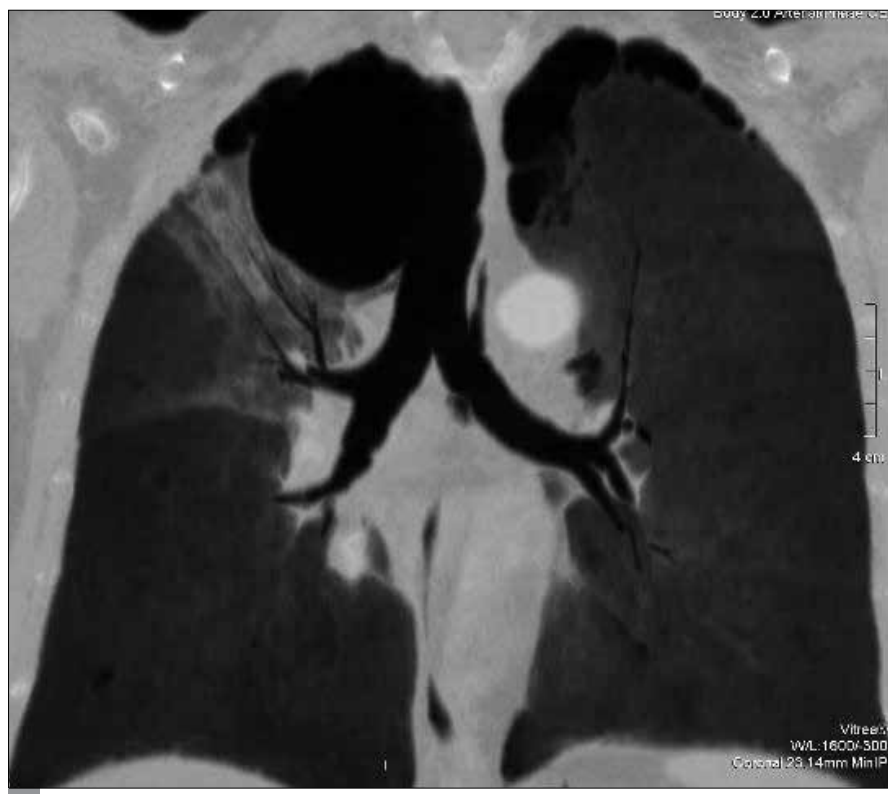

Figure 3. Thorax CT showing a cavitary lesion size of $56 \times 71 \mathrm{~mm}$ and ground-glass opacity in the right upper lobe (coronal reformatting)

were consolidated areas with air bronchograms, septal thickening, and fibrotic shrinkage in the posterior segment of right upper lobe, superior-posterior, and lateral segments of lower lobe. There was no residual mass. Because of a preliminary diagnosis of radiation pneumonitis, systemic steroids and non-specific antibiotic therapy were started. Bronchoscopic examination could not be performed due to the poor general health of the patient. Cultures of the sputum and acido-resistant bacillus examinations were negative. Based on the improvement on the chest X-ray, antibiotic therapy was discontinued, and steroid therapy was tapered down gradually (Figure 4). In the control $\mathrm{CT}$, the radiation pneumonitis was completely healed by fibrosis, and there was no change in the size of the cavity 2 months after the therapy. The patient's consent was taken for the case report.

\section{DISCUSSION}

Cavity in the lung develops by several mechanisms, which are central necrosis of a mass as a result of rapid tumor growth exceeding the amount of blood supply, causing development of a cavity, or a cavity may develop secondary to abscess formation behind an obstructive lesion. In addition to these, lung metastasis, infections, non-infectious inflammatory diseases, chemotherapeutics, and radiotherapy may be responsible from the development of cavity. Radiation-induced cavity development is rarely reported in the literature. It usually develops in a fibrosis area after a superimposed infection, and septations can be present in the cavity $(3,4)$. A combination of factors, such as chemotherapy, surgery, and infections, contributes to this complication (5).

But, in our case, the expected fibrosis reaction against radiotherapy was not sufficiently developed. Fibrosis was only localized to the parenchyma of radiation pneumonitis, and the tumor area was completely replaced by an unexpected large cavitary lesion after the treatments. This cavity did not contain any septation or findings of an infection. Additionally, there was no sign of tumor lysis syndrome in the case. 


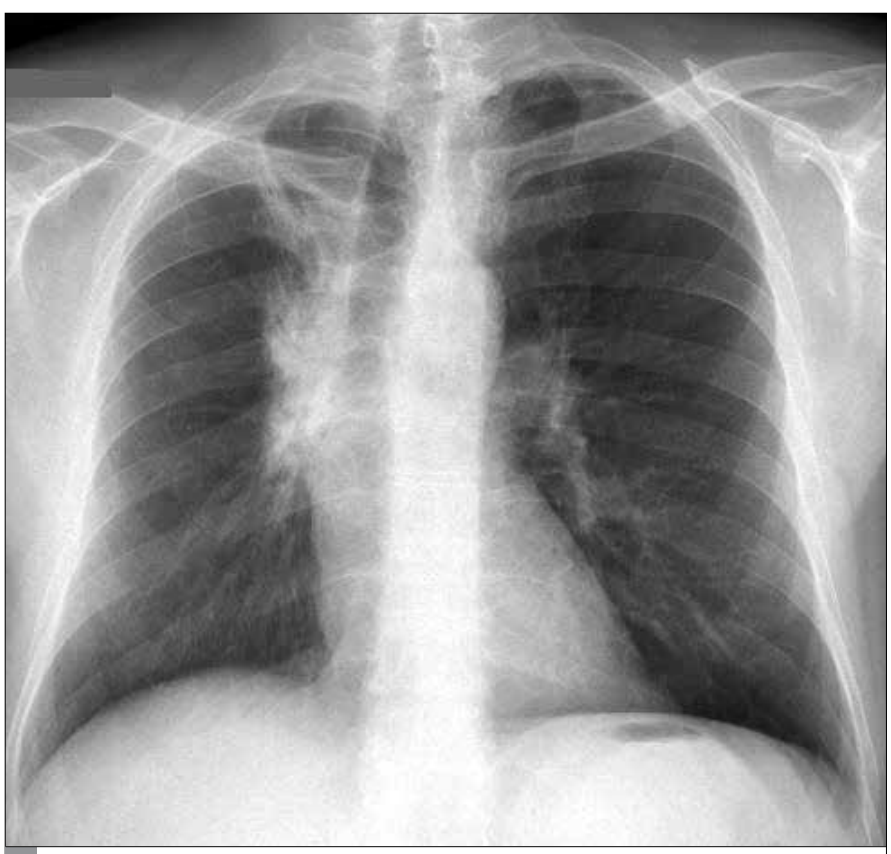

Figure 4. Chest X-ray showing cavity and right hilar widening after treatment

It has been reported that radiation-induced lung diseases may occur $20 \%-63 \%$ after thoracic radiotherapy (6). Development of a cavity is also very rarely seen as secondary to necrosis 6-12 weeks after radiotherapy. It has been reported that cavity formation can cause late complications, such as spontaneous pneumothorax, superinfection, or bronchopleural fistula $(2,7)$. In this case, both a cavitary lesion and radiation pneumonitis developed concomitantly about 10 weeks after radiotherapy.

Several other factors can also influence the development of lung damage after radiotherapy. The patient's age, previous or concomitant chemotherapy, and techniques of radiotherapy can alter the toxic effects of radiation. The three most important influential technical factors of radiotherapy are the volume of the lung exposed to radiation, total radiation dose, and fractionation. While radiation pneumonitis is very unusual when the total dose is less than $20 \mathrm{~Gy}$, it almost invariably develops when the total dose is above $40 \mathrm{~Gy}$ (2). In our case, although the mass tended to become a cavity, we think that this process gained speed because of the conformal radiotherapy technique, and then, an exaggerated reaction was developed.

The clinical picture of radiation pneumonitis is generally less symptomatic than infectious diseases. The presence of radiological findings outside the field of radiotherapy will also support infectious processes. Development of a cavity in the radiation-induced fibrotic lung area usually suggests an infectious process; however, it can also rarely develop secondary to radiotherapy itself, as seen in this case (2, 8 ). We excluded the infections with sputum cultures and acido-resistant bacillus examinations.

Time of initiation and accomplishment of radiotherapy, amount of dose used, dose application area, and review of radiologic findings initially are helpful in the differential diagnosis. However, the diagnosis can still be difficult in some cases. In such cases, evalu- ating the response to the given treatment will help in the differential diagnosis (2). In recent years, with the new development of radiotherapy applications with three-dimensional conformal radiotherapy, intensity-modulated radiotherapy, and stereotactic radiotherapy, there is a possibility of using smaller areas of treatment fields, causing less toxicity $(9,10)$. Three-dimensional conformal radiotherapy protects normal tissue better; so, higher doses can be used. Three-dimensional localization of the tumor and radiation-sensitive tissues can be protected by a CT-simulator device developed specifically for radiation therapy. Using this method in conjunction with chemotherapy may keep the side effects within the tolerance limits (11). Implementation of new techniques may also result in milder side effects of radiotherapy or the development of atypical radiologic findings. Some of the atypical findings are late development of or increase in the amount of pleural fluid, consolidation, and radiation-induced fibrosis causing bronchial occlusion $(2,11)$. As reported in our case, replacement of the mass with a cavity may be considered an addition to these findings.

Cavitation is a known complication of lung cancers, especially in squamous cell lung cancer. In our case, the mass also contained an area of a small cavity and necrosis before the treatment. Ten weeks after the treatment with three-dimensional conformal radiotherapy and simultaneous chemotherapy apparent cavitation and radiation pneumonitis were seen in the $\mathrm{CT}$ scan. But, the radiologic view of cavitation was not similar to an infectious process or to expected development of radiation-induced cavity. A meaningful clinical recovery was seen after corticosteroid therapy started for radiation pneumonitis, with improvement in the radiologic and laboratory findings. Follow-up chest CT scans showed that the radiation pneumonitis area converted to fibrosis, but no significant change was observed in the size or appearance of the cavity in the repeated scans. It is known that cavity related to the radiotherapy may develop in the fibrosis area or secondary to superinfections. In our case, exceptionally, the tumor completely left its place to a cavity with an approximate size. This may be a result of conformal radiotherapy, which protected the surrounding tissue and exposed the tumor area to higher doses of radiotherapy. In conclusion, we report a cavitary lesion as an atypical finding of radiation-induced lung disease after conformal radiotherapy. Knowing the spectrum of atypical findings is important in the management of patients after radiotherapy.

Informed Consent: Informed consent was obtained from patient who participated in this study.

Peer-review: Externally peer-reviewed.

Author contributions: Concept - A.K., E.A., B.A.Y.; Design - E.A., B.A.Y.; Supervision - A.K., H.C.H.; Resource - A.S.; Materials - E.A., A.S.; Data collections or processing - E.A., B.A.Y.; Analysis or Interpretation - E.A., B.A.Y., A.K., H.C.H.; Literature search - A.S., E.A.; Writing - E.A., A.S., B.A.Y.; Critical reviews - A.K., H.C.H. Conflict of Interest: No conflict of interest was declared by the authors.

Financial Disclosure: The authors declared that this study has received no financial support.

\section{REFERENCES}

1. Williams JP, Johnston CJ, Finkelstein JN. Treatment for radiation-induced pulmonary late effects: spoiled for choice or looking in the wrong direction? Curr Drug Targets 2010; 11: 1386-94. [CrossRef] 
2. Choi YW, Munden RF, Erasmus JJ, Park KJ, Chung WK, Jeon SC, et al. Effects of radiation therapy on the lung: radiologic appearances and differential diagnosis. Radiographics 2004; 24: 985-98. [CrossRef]

3. Tuddenham WJ. Glossary of terms for thoracic radiology: Recommendations of the Nomenclature Committee of the Fleischner Society. AJR Am J Roentgenol 1984; 143: 509-17. [CrossRef]

4. Gill RR, Matsusoka S, Hatabu H. cavities in the lung in oncology patients: Imaging overview and differential diagnoses. Applied Radiology 2010; 39: 10-21.

5. Mesurolle B, Qanadli SD, Merad M, Mignon F, Baldeyrou P, Tardivon A, et al. Unusual radiologic findings in the thorax after radiation therapy. Radiographics 2000; 20: 67-81. [CrossRef]

6. Jenkins $P$, Welsh $A$. Computed tomography appearance of early radiation injury to the lung: correlation with clinical and dosimetric factors. Int J Radiat Oncol Biol Phys 2011; 81: 97-103. [CrossRef]
7. Frytak S, Lee RE, Pairolero PC, Arnold PG, Shaw JN. Necrotic lung and bronchopleural fistula as complications of therapy in lung cancer. Cancer Invest 1988; 6: 139-43. [CrossRef]

8. Libshitz HI, DuBrow RA, Loyer EM, Charnsangavej C. Radiation change in normal organs: an overview of body imaging. Eur Radiol 1996; 6: 786-95. [CrossRef]

9. Vogelius IR, Westerly DC, Aznar MC, Cannon GM, Korreman SS, Mackie TR, et al. Estimated radiation pneumonitis risk after photon versus proton therapy alone or combined with chemotherapy for lung cancer. Acta Oncol 2011; 50: 772-6. [CrossRef]

10. Kaplan B. Radiotherapy in non-small cell lung cancers. Turkiye Klinikleri J Thorax Dis 2004; 2-3; 244-8.

11. Machtay M. Pulmonary Complications of Anticancer Treatment. Abeloff: Abeloff's Clinical Oncology, $4^{\text {th }}$ ed. Churchill Livingstone, An Imprint of Elsevier; 2008. p.969-981. 